\title{
Suppression Effect of Sensation Seeking on the Relationship between General Self-Efficacy and Life Satisfaction among Emerging Adults ${ }^{1}$
}

\section{Eyüp Çelik}

Asst. Prof., Sakarya Üniversitesi, eyupcelik@sakarya.edu.tr

\section{Lokman Koçak}

Sakarya Üniversitesi, lokmankocak@msn.com

The aim of the present study is to examine suppression effect of sensation seeking in the relationship between general self-efficacy and life satisfaction among emerging adults. The data were gathered using Satisfaction with Life Scale, General Self-efficacy Scale, and Brief Sensation Seeking Scale (BSSS-8). Correlation and regression analysis were performed to determine whether there is a relationship among variables and to test whether sensation seeking has suppression effect in the relationship between general self-efficacy and life satisfaction. The findings of the study demonstrated that general self-efficacy positively related to life satisfaction and sensation seeking, but the life satisfaction didn't relate to sensation seeking significantly. Although no significant relationship was found between sensation seeking and life satisfaction after the correlation analysis, after the regression analysis sensation seeking variable was found to both significantly predict life satisfaction and increase general self-efficacy's capability to predict life satisfaction. These results prove that sensation seeking has suppression effect in the relationship between general self-efficacy and life satisfaction.

Keywords: suppression effect, sensation seeking, general self-efficacy, life satisfaction, emerging adult

\section{INTRODUCTION}

Emerging adulthood can be regarded as the period which corresponds to the age interval of university students as a critical developmental stage of humans. In the related literature, emerging adulthood is defined as the transition stage from adolescence to adulthood which covers the approximate age interval of 18-23. In this period, which is characterized with experience and quest, individuals carry on their search for their own

\footnotetext{
${ }^{1}$ Part of this study was presented an oral presentation at the International Academic Conference on Global Education, Teaching and Learning (IAC-GETL 2018).

Citation: Celik, E., \& Koçak, L. (2018). Suppression Effect of Sensation Seeking on the Relationship between General Self-Efficacy and Life Satisfaction among Emerging Adults. International Journal of Instruction, 11(4), 337-352. https://doi.org/10.12973/iji.2018.11422a
} 
identity, future career path, and lifestyle (Santrock, 2012). Search for identity, instability (love, work, education, etc.), self-focus, being in two minds (am I an adolescent or adult?) are among the fundamental characteristics of adults (Arnett, 2006 cited in Santrock, 2012). In this regard, university years can be regarded as the last years of adolescence and first years of emerging adulthood.

After achieving intense examination periods and getting into university, an emerging adult may encounter new and diverse challenges. Several factors such as being away from family, undertaking more responsibilities as compared to high school years and the anxiety for finding a job may result with problems and unhappiness for adults. Emerging adulthood may be more challenging for individuals that fail to healthily get over adolescence and still bear the traces of this period. This challenging period may impair the life quality of emerging adults and reduce their life satisfaction which is a critical indicator of their mental health. In this context, evaluation of the variables related to life satisfaction hold particular importance in adolescence and emerging adulthood periods. Determination of the variables which are likely to have a positive correlation with life satisfaction may help emerging adults in coping with the challenges they face in university years. In addition, this may increase their motivation, thereby making them feel better with increased self-confidence and self-esteem. The relatively higher focus on the concept of life satisfaction among adults brings about the need for more studies on the same subject among emerging adults. On the other hand, determination and evaluation of the factors related to life satisfaction among emerging adults will enable a healthier development of emerging adults through contributing to the related literature.

\section{Life Satisfaction}

Life satisfaction, also regarded as the cognitive dimension of subjective well-being, is defined as the cognitive judgments and assessments of individuals as to the extent to which they are satisfied with their lives (Diener \& Suh, 1997; Erturan, Aktepe, Kocaman, Sönmez, Başak, Ceyhan, \& Baysal Akkaya, 2014). Life satisfaction has been stated to be the life quality perceived by individuals and assumed to be related to the difference between what they desire and what they have (Çivitçi, 2009; Frisch, 2006). Lower difference between these concepts is an indication of higher life satisfaction (Diener, Oishi, \& Lucas, 2003). Studies on satisfaction of adolescents with their lives showed that sensation seeking (Çelik, 2015), assertiveness level (Dönmez, 2007), expectancy, self-esteem and internal control (Gilman and Huebner, 2006) have a positive correlation; peer rejection, being subject to stressful events (Huebner, Antaramian, Hills, Lewis, \& Saha, 2010) and loneliness (Chipuer, Bramston, \& Pretty, 2003) have a negative correlation with life satisfaction.

Studies on emerging adults showed that, life satisfaction has a positive correlation with successful identity status (Özgüngör, 2009), self-esteem (Lucas, Diener, \& Suh, 1996; Yetim, 2003), self-efficacy (Akın \& Akın, 2016) and proactive personality (Çelik \& Raba, 2017); and a negative significant correlation with interpersonal conflicts (Koçak, 2016) and depression, desperation and chronic anxiety (Gündoğar, Gül, Uskun, Demirci, \& Keçeci). Moreover, a study on psychological well-being and life satisfaction levels of international university students indicated that, life satisfaction levels of 
students significantly varied on the basis of their motherlands (Şeker \& Akman, 2015). On the other hand, Çelik and Raba (2017) reported that there was no correlation between life satisfaction and sensation seeking.

\section{General Self-efficacy}

The concept of self-efficacy, initially introduced by Bandura (1977), is one of the important constituents of social cognitive theory. Self-efficacy is the self-evaluation of an individual as to whether he/she has the skills required to achieve a goal or completing a task. (Bandura, 1994). Umaz (2010) suggested that, self-efficacy is an intrinsic response of an individual, who faces stressful or challenging situations, to the question "how can I cope with this situation". Luszczynska, Scholz, and Schwarzer (2005) stated that, self-efficacy is the personal belief of an individual related to the extent to which he/she can do with his/her existing skills against a challenging situation.

Bandura (1986) asserted that, self-efficacy should be characterized with specific tasks; different tasks may require different skills which in turn may result with diversification of self-efficacy beliefs, hence emergence of general and task-specific self-efficacy beliefs. In this respect, general self-efficacy can be defined as the extent of the belief of an individual on his/her capability to cope with challenging and stressful life events; whereas specific self-efficacy can be defined as the belief of an individual on his/her capability to achieve realm and task-specific skills (Akgündüz, 2013; Aydıner, 2011).

Literature studies on investigation of the relationship between general self-efficacy and life satisfaction (Burger \& Samuel, 2017; Çıkrıkçı \& Odacı, 2016) showed that selfefficacy was an important predictor of life satisfaction. Studies performed with emerging results also showed that the concepts of self-efficacy and life satisfaction are accompanied by different variables. For instance Sahranç (2008) reported that, general self-efficacy level has a positive and direct effect on life satisfaction. These findings indicate that increasing general self-efficacy level is very likely to increase life satisfaction. Akın and Akın (2016) reported that, social self-efficacy positively predicted the beliefs and emotions related to academic potential; likewise social self-efficacy positively predicted social self-efficacy. Additionally, social self-efficacy was found to play a negotiating role in the relationship between academic-potential-based beliefs and emotions, and life satisfaction. The results of another research showed that, female students had higher levels of life satisfaction as compared to male students, whereas male students had higher general self-efficacy levels when compared with female students. Also, a positive and significant relationship was detected between students' life satisfaction and general self-efficacy levels (Şahan, Tekin, Yıldız, Eraslan, Yıldız, Sim, \& Yarar, 2012).

\section{Sensation Seeking}

Individuals may tend to several risky behaviors due to several reasons such as proving themselves, gaining identity, exhibiting their difference and finding more pleasure in life. As a determinant of individuals' level of exhibiting risky behaviors, sensation seeking is defined as an individual's seeking new, complex and exciting experiences through venturing physically, socially, legally and financially risky situations 
(Zuckerman, 1994). As conveyed by Zuckerman and Kuhlman (2000), a sensation seeking individual feels good with new and amusing experiences, and evaluates a risky behavior as riskless even though he/she never experienced the situation and does not know about its risks.

The relationship between sensation seeking and life satisfaction were addressed in a number of studies. Çelik (2015) reported in a study conducted with adolescents that sensation seeking has a suppression and moderator effect in the relationship with life satisfaction; and additionally, it increased the negative effect of self-concealment on life satisfaction. The findings of another study indicated that there was no direct effect of sensation seeking on life satisfaction (Oishi, Schimmack, \& Colcombe, 2003). Stegman (2011) studied the relationships between four subscales of sensation seeking (excitement and sensation seeking, pursuit of experience, disinhibition (loss of conditioned reflex) and susceptibility to trouble) and life satisfaction and found a negative correlation between disinhibition and susceptibility to trouble subscales and life satisfaction. A study on emerging adults showed that students' level of life satisfaction significantly varied depending on their sensation seeking levels; students with low sensation seeking levels had higher life satisfaction levels compared to those with higher sensation seeking levels (Çelik \& Turan, 2016).

It was reported that sensation seeking levels varied based on developmental periods; and thrill seeking levels that increase in adolescence decrease in adulthood (Chambers, Taylor, \& Potenza, 2003). By nature, adolescence period can be regarded as a stressful and turbulent time period. Sensation seeking adolescents may exhibit several risky behaviors such as alcohol and substance abuse (Cicognani \& Zani, 2011; Kopstein, Crum, Celentano, \& Martin, 2001), unprotected sexual intercourse (Donohew Zimmerman, Cupp, Novak, Colon, \& Abell, 2000), careless driving (Curran, Fuertes, Alfonso, \& Hennessy, 2010) and tending to dangerous sports activities (Diehm \& Armatas, 2004) due to the reasons such as becoming distinct or gaining more pleasure from life. Such behaviors may have negative impacts on adolescents' development and result in irremediable habits and regrets (Çelik, 2015). The damages likely to occur during adolescence may manifest themselves in emerging adulthood as well. Accordingly, investigation of the sensation seeking variable and other variables related to general self-efficacy can enable determination of positive and negative aspects of sensation seeking.

General self-efficacy, also referred as the capability to cope with hard and stressful conditions, can also be defined as the awareness of individuals as to what they are capable of and their personal efficacy belief (Scherbaum, Cohen-Charash, \& Kern, 2006). Self-efficacy has been commonly stated to be an important factor in alleviation of individuals' risky behaviors and improvement of their social skills (Balkıs, Duru, \& Buluş, 2005). Additionally, a negative correlation was detected between depression, aggressive behaviors and self-efficacy (Balkıs et al., 2005; Ehrenberg, Cox, \& Kopman, 1991). These findings indicate that general self-efficacy can decrease depression and risky behaviors, and increase life satisfaction. Individuals with high sensation seeking levels have lower perceived stress levels regarding their lives (Jorgensen \& Johnson, 
1990) and they are more apt to participate in activities that make them feel happy (Zuckerman, 1990); which indicates that sensation seeking has a positive impact on the relationship between general self-efficacy and life satisfaction. Emerging adults that avoid risky behaviors and increase their life satisfaction as a result of their general selfefficacy may tend to new, useful and amusing experiences in a more conscious and careful way, thus increasing the predictive effect of general self-efficiency on life satisfaction. It can be concluded that limited number of works are available on general self-efficacy and life satisfaction of emerging adults, in these works only correlational and predictive relations between general self-efficacy and life satisfaction were studied, and the possible effect of other factors in the relationship between general self-efficacy and life satisfaction were not sufficiently addressed. In this regard, investigation of the suppression effect of sensation seeking in the relationship between general self-efficacy and life satisfaction was aimed in the present work.

\section{METHOD}

Relational screening model, among quantitative research methods, was used in this work. Reportedly, determination of a variable's status and estimation of another variable's status is possible through the use of this method (Karasar, 2006). In this context, this work was carried out to investigate the relationships between life satisfaction, general self-efficacy and sensation seeking levels of university students.

\section{Study Group}

The study group consists of 455 university students (273 female, 169 male) studying at Sakarya University. The age range of participants is $18-21$. 13 students in the study group did not state their genders. Convenience sampling method was used for selection of the participants. As reported by Creswell (2002), convenience sampling method is an effective method for collection of the research data from participants that voluntarily participate in the research. Accordingly, convenience sampling method was preferred as a means for enabling voluntary participation to increase the validity and reliability of the research and obtain more accurate results.

\section{Data Collection Tools}

\section{Satisfaction with Life Scale}

This scale, used for determination of the satisfaction gained by individuals from their lives, was developed by Diener, Emmons, Larsen, and Griffin (1985), and adopted into Turkish by Köker (1991), Durak, Şenol Durak, and Gençoz (2010). Satisfaction with Life Scale is a single-dimension and 5 items which were developed to evaluate the life satisfaction levels of individuals. The scale is in Likert-7 type ( $1=$ not suitable at all, $7=$ very suitable) and 5 items. The scale's test-retest reliability coefficient was found as .85 , and its item-test correlations were calculated between .71 and .80. Durak et al. (2010), on the other hand, calculated the reliability coefficient of the scale as .81, and after their confirmatory factor analysis performed to determine the validity, they found the fit index values as $\chi^{2} / \mathrm{df}=2.026, \mathrm{IFI}=.99, \mathrm{TLI}=.98, \mathrm{CFI}=.99$, and $\mathrm{RMSEA}=.43$. The internal consistency coefficient was found as.86 in the present study. The lowest and highest 
possible values received from the scale were 5 and 35, respectively. High scores indicated high satisfaction levels with life, and low scores indicated low satisfaction levels with life.

\section{General Self-efficacy Scale}

The scale was developed by Schwarzer and Jerusalem (1995) and adopted into Turkish by Aypay (2010). High scores received from the scale were indicative of high general self-efficacy levels, and low levels indicated low general life efficacy levels. Alpay (2010) examined the psychometric properties of Likert-4 type scale ( $1=$ completely wrong, $4=$ completely correct) which consisted of 10 items, and reported that the scale had a two-factor structure. In the study, which was conducted for adoption of the scale into Turkish, the scale's alpha coefficient, calculated on the basis of single dimension, was found as .83 , and its test-retest result was found as .80 . The solutions with single and double factors were estimated for the other versions of the scale, and after the analyses its two-factor structure was rejected (Aypay, 2010; Scholz, Dona, Sud, \& Schwarzer, 2002). Also, Uysal (2013) reevaluated the factor structure of the scale by additionally using general self-efficacy scale, and reported after the analysis that the scale had a single-factor structure. In light of these previous findings, in this research, exploratory factor analysis was performed to examine the factor-structure of the scale, and after the analysis, the scale items were found to have a single-factor structure which ranged between .57 and .75 factor loading values. In this research, the alpha coefficient, calculated on the basis of single dimension, was found as .88 .

\section{Brief Sensation Seeking Scale (BSSS-8)}

The scale was developed by Hoyle, Stephenson, Palmgreen, Lorch, and Donohew (2002), and adopted into Turkish by Çelik and Turan (2016). The Turkish version of the likert-5 type scale ( $1=$ completely agree, $5=$ completely disagree) consisting of eight items has a single-dimension structure with no reverse scored items. High scores received from the scale indicate high sensation seeking levels and low scores indicate low sensation seeking levels. In the study carried out for adaptation of the scale into Turkish, the reliability coefficient of the scale was calculated as .79 , and the fit index values were found acceptable $(\mathrm{x} 2 / \mathrm{sd}=4.46, \mathrm{RMSEA}=.07, \mathrm{GFI}=.96, \mathrm{CFI}=.94, \mathrm{IFI}=$ $.94, \mathrm{NFI}=.93, \mathrm{AGFI}=.93$, and NNFI $=.91)$. The scale's item-test correlations were found to range between .22 and .59 . The internal consistency coefficient was found as .78 in the present study.

\section{Data Analysis}

Regression analysis was performed in an attempt to determine whether sensation seeking had a suppressive effect on the relationship between general self-efficacy and life satisfaction. Accordingly, it was firstly investigated whether research data were agreeable with the regression premises. In this regard, Mahalanobis distance values were detected and an evaluation as to whether multi-variable extreme values were available in the data set was conducted, and consequently no extreme values impairing normality and linearity were detected. Normal distribution of the data set was also investigated on the basis of skewness and kurtosis. Multicollinearity among independent 
variables was checked through VIF (Variance inflation factors method) and CI (Condition Index Numbers method) and no multicollinearity was detected. In the literature, VIF values lower than 10 and CI values lower than 30 were reported to be indicative of no multicollinearity issue (Tabachnick \& Fidell, 2007). In light of these analyses, regression analysis was chosen to investigate the suppressive effect of sensation seeking on the relationship between general self-efficacy and life-satisfaction. The findings on regression premises are given in Table 1.

Table 1

Findings on Regression Analysis Premises

\begin{tabular}{lllll}
\hline Variables & Skewness & Kurtosis & VIF & CI \\
\hline Life satisfaction & -.37 & -.45 & & 1.00 \\
General Self-efficacy & -.09 & .14 & 1.08 & 8.57 \\
Sensation seeking & .01 & -.39 & 1.08 & 12.68 \\
\hline
\end{tabular}

\section{FINDINGS}

The results of the correlation analysis performed to examine the relationships between the variables show that life satisfaction as a positive significant relationship with general self-efficacy $(\mathrm{r}=.38)$, and no significant relationship with sensation seeking. Also, a positive significant relationship was found between general self-efficacy and sensation seeking $(r=.29)$ as well. Correlation analysis and descriptive statistical results are given in Table 2.

Table 2

Correlation Analysis and Descriptive Statistical Results

\begin{tabular}{llll}
\hline Variables & 1 & 2 & 3 \\
\hline Life satisfaction & 1 & & \\
General Self-efficacy & $.38^{* *}$ & 1 & \\
Sensation seeking & .02 & $.29^{* *}$ & 1 \\
\hline $\bar{X}$ & 23.00 & 28.09 & 25.02 \\
$S D$ & 6.83 & 5.49 & 6.53 \\
\hline
\end{tabular}

** $p<0.01$

\section{The Finding on the Suppressive Effect of Sensation seeking}

Staged regression analysis was performed to investigate the suppressive effect of sensation seeking on the relationship between life satisfaction and general self-efficacy. The results of the regression analysis are given in Table 3.

Table 3

Results of Regression Analysis

\begin{tabular}{clllllll}
\hline \multicolumn{1}{c}{ Dependent Variable } & Predictor Variables & $B$ & $S S$ & $\beta$ & $t$ & $p$ & $R^{2}$ \\
\hline Stage 1 Life satisfaction & Constant & 9.65 & 1.54 & & 6.24 & .000 & \multirow{2}{*}{.14} \\
& General Self-efficacy & .47 & .05 & .38 & 8.80 & .000 & \\
\hline Stage 2 Life satisfaction & Constant & 11.28 & 1.70 & & 6.62 & .000 & \\
& General Self-efficacy & .51 & .06 & .41 & 9.11 & .000 & .15 \\
& Sensation seeking & -.11 & .05 & -.10 & -2.24 & .02 & \\
\hline
\end{tabular}


It can be inferred from Table 3 that in the first stage of regression, general self-efficacy significantly predicted life satisfaction $(\beta=.38, \mathrm{p}<.01)$. In the second stage of regression analysis, both general self-efficacy $(\beta=.41, p<.01)$ and sensation seeking $(\beta=-.10$, $\mathrm{p}<.05)$ significantly predicted life satisfaction. In the second stage of regression analysis inclusion of sensation seeking variable into the regression model increased the lifesatisfaction-predicting capacity of general self-efficacy from .38 to .41 . Although no significant relationship was found between sensation seeking and life satisfaction after the correlation analysis by which the relationship between variables was examined as indicated in Figure 1, after the regression analysis sensation seeking variable was found to both significantly predict life satisfaction and increase general self-efficacy's capability to predict life satisfaction. Moreover, the regression analysis result indicating the increase in the capability of general self-efficacy to predict life satisfaction further indicates that sensation seeking has a suppressive effect on the relationship between general self-efficacy and life satisfaction.

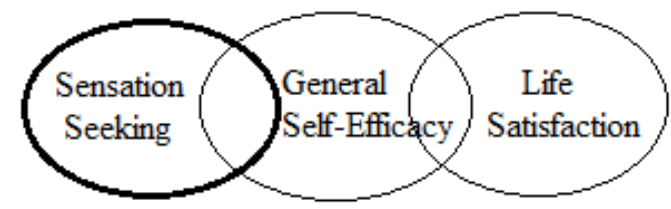

Figure 1

Suppressive Role of Sensation seeking

\section{DISCUSSION, CONCLUSION AND SUGGESTIONS}

Research finding as to the positive significant relationship between general self-efficacy and life satisfaction is consistent with those of other related studies (Burger \& Samuel, 2017; Caprara \& Steca, 2005; Coffman \& Gilligan, 2002; Çıkrıkçı \& Odacı, 2016; Gilman \& Huebner, 2006; Reigal, Videra, \& Gil, 2014; Şahan et al., 2012). On the other hand, no study was found in the literature on the relationship between general selfefficacy and sensation seeking. However, it was reported in a study on adolescents that adolescents with high sensation seeking and low self-efficacy levels exhibited risky behaviors (risky driving, alcohol and substance abuse) at higher levels (Smorti, 2014). The finding stating that there is no significant relationship between life satisfaction and sensation seeking is agreeable with the findings of various studies (Çelik \& Raba, 2017; Oishi et al., 2003). In addition, some of the previous research findings (Çelik, 2015) indicate that there is a positive significant relationship between sensation seeking and life satisfaction, whereas others (Çelik \& Turan, 2016) indicate that there is a negative significant correlation between thrill seeking and life satisfaction. Sensation seeking increases the self-confidence of adolescents (Romer, 2010), improves their skills (Çelik, 2015) and enables them to interact with their peers (Yanovitzky, 2005), however, it may lose its influence during the transition from adolescence to adulthood due to several reasons. These underlying reasons may be the tendency of the individual in emerging adulthood stage to exhibit behaviors consistent with the profession he/she intends to get involved in the future; the reduced effect of peer effect with advancing age and emergence of different fields of responsibility in life; increase in the socialization efforts 
of individual resulting from the fading effect of adolescent self-centeredness; and gradual decrease in the life energy which is at its peak in adolescence period. Accordingly, the relationship between sensation seeking and life satisfaction can be expected to be insignificant or negative in studies on university students; and positive in studies on adolescents.

Following the investigation of relationship between general self-efficacy, life satisfaction and sensation seeking, predictive relationships between these variables were also addressed. In the first stage of the conducted regression analysis, general selfefficacy was found to significantly predict life satisfaction. This finding shows consistency with those of the related literature studies (Akın \& Akın, 2016; Charrow, 2006; Çıkrıçç \& Odacı, 2016; Giovanni, Gerbino, Pastorelli, \& Caprara, 2007; Sahranç, 2008). In the second stage of regression analysis, the capability of general selfefficacy to predict life satisfaction was found to increase as a result of inclusion of sensation seeking variable into the regression model. This is indicative of the fact that sensation seeking has a suppressive effect on the relationship between general selfefficacy and life satisfaction. In the literature, no study was encountered related to the suppressive effect of sensation seeking on the relationship between general self-efficacy and life satisfaction. However, some of the studies carried out with similar variables are in agreement with those of the present research. For instance, Çelik and Raba (2017) reported that, the capability of proactive personality to predict life satisfaction increased after inclusion of thrill seeking, which was not significantly correlated with life satisfaction, was included in the regression analysis. In another research, sensation seeking was found to have a suppressive effect on the relationship between life satisfaction and self-concealment (Çelik, 2015). It can be inferred from these findings that sensation seeking may have a suppressive effect on the increase in the capability of these variables to predict life satisfaction. These findings also show that besides its adverse and undesirable effects, (Diehm \& Armatas, 2004; Jonah, Thiessen, \& AuYeung, 2001; Kopstein et al., 2001; Reyes-Pulliza, Moscoso-Alvarez, RodriguezFigueroa, \& Coln, 2014) sensation seeking, as the addressed variable, may have positive effects as well. New experiences and risk-taking behaviors may from time to time result in adverse outcomes, thereby inducing an adverse effect on individuals' satisfaction with their lives. However, societies' requirement for sociable, challenging and innovative individuals aside from conformist and accomplished ones indicate that sensation seeking may contribute to individual and social development; and the finding stating that individuals with specific characteristics such as discovering, enthusiastic, challenging and curious roles (Cloninger, Svrakic, \& Przybeck 1993; Zuckerman, 1994) further suppers this notion.

Sensation seeking may not always drag individuals into dangerous and risky behaviors. Individuals may desire to experience new and entertaining adventures and such activities may increase their life satisfaction. General self-efficacy, which is known to reduce risky behaviors (Balkis et al., 2005), may reach a more balanced level, which may in turn enable individuals to embark on new and entertaining adventures. Increased sensation seeking levels among individuals (with high sensation seeking levels), who are aware of their potentials and have the capability to cope with challenges, may encourage them to 
experience new challenges which are likely to contribute to their personal development. Moreover, the university students, constituting the study group of this research, may be directed towards sole academic success and neglect social activities as a result of employment anxiety. Individuals with high academic success may gain increased general self-efficacy levels. However, such individuals that do not spare time for new and entertaining experiences and that fail to take risk at critical situations may have reduced levels of satisfaction with their lives. Nevertheless, sensation seeking may embellish university life which is in a sense stabilized by general self-efficacy. Participation of individuals with academic success into new and entertaining activities may increase their life satisfaction. Additionally, association of the factors such as low stress, high happiness (Jorgensen \& Johnson, 1990; Smith, Ptacek, \& Smoll, 1992), extraversion (Costa \& McCrae, 1992), which are known to boost individuals' life satisfaction with sensation seeking indicates that, sensation seeking may have positive effects on life satisfaction along with related variables.

In this research, general self-efficacy explains $38 \%$ of the variance in life satisfaction. Sensation seeking is likely one of the reasons which is not explained by general selfefficacy in the variance of life satisfaction. In this context, sensation seeking may suppress the adverse effects of general self-efficacy on life satisfaction, thus increasing the capability of general self-efficacy to predict life satisfaction. Research findings consequently show that sensation seeking has a suppressive effect on the relationship between general self-efficacy and life satisfaction.

Emerging adulthood can be defined as an important stage in the transition from adolescence to adulthood. In this period, individuals are faced with more tasks and responsibilities at the beginning of their university life which may induce a more intense anxiety for their future. This may have negative impacts on individuals' lives and reduce their life satisfaction. Particularly, a stressful adolescence period with negative impacts of sensation seeking may pose a serious risk on individuals' life satisfaction in university years. Increasing individuals' coping capabilities through general self-efficacy, thus enabling them to successfully use their potentials may increase their life satisfaction. General self-efficacy may both increase life satisfaction and reduce it through the desire to embark on new experiences, and it may take on a more flexible and creative form by the effect of sensation seeking. In this regard, students' life satisfaction, general selfefficacy and sensation seeking levels can be determined through surveys at high schools and universities, and accordingly, students with low satisfaction levels can be provided with required psychological support. Also, determination of factors that have positive and negative impacts on life satisfaction can contribute to improvement of preventive counseling services. In light of the finding that sensation seeking has a suppressive effect on the relationship between general self-efficacy and life satisfaction, the effect of sensation seeking on relationships between life satisfaction and other variables can be the subject of future studies. Finally, integration of sensation seeking into positive fields such as socializing, taking responsibilities and being innovative may contribute to reducing the risky aspects of sensation seeking during adolescence and emerging adulthood and improving life quality of individuals. 
Selection of 455 students from Sakarya University Faculty of education as the study group constitutes a limitation of the present research. Conducting further researches with numerous samples from different age groups, provinces, universities and faculties to experimentally investigate the concepts of life satisfaction, general self-efficacy and sensation seeking holds importance for generalizability of these research findings.

\section{REFERENCES}

Akın, A., \& Akın, Ü. (2016). Academic potential beliefs and feelings and life satisfaction: the mediator role of social self-efficacy. Revista de Psicología Social/International Journal of Social Psychology, 31/3, 500-520.

Akgündüz, Y. (2013). Konaklama işletmelerinde iş doyumu, yaşam doyumu ve öz yeterlilik arasındaki ilişkinin analizi. CBÜ Sosyal Bilimler Dergisi, 11/1, 181-204.

Aydıner, B. B. (2011). Üniversite öğrencilerinin yaşam amaçlarının alt boyutlarının, genel öz-yeterlik, yaşam doyumu ve çeşitli değişkenlere göre incelenmesi (Yayınlanmamış Yüksek Lisans Tezi). Sakarya Üniversitesi, Eğitim Bilimleri Enstitüsü, Sakarya.

Aypay, A. (2010). The adaptation study of general self-efficacy (GSE) scale to Turkish. Inonu University Journal of the Faculty of Education (INUJFE), 11/2, 113-132.

Balkıs, M., Duru, E., \& Buluş, M. (2005). Şiddete yönelik tutumların öz yeterlik, medya, şiddete yönelik inanç, arkadaş grubu ve okula bağl1lık duygusu ile ilişkisi. Ege Ĕ̈itim Dergisi, 2:, 81-97.

Bandura, A. (1977). Self-efficacy: Toward a unifying theory of behavioral change. Psychological Review, 84/2, 191-215.

Bandura, A. (1986). Social foundations of thought on action: A socian cognitive theory. Englewood Cliffs; NJ, Prentice Hall.

Bandura, A. (1994). Self-efficacy. In R. J. Corsini (Ed.), Encyclopedia of psychology (2nd ed., 3, 368-369). New York: Wiley.

Burger, K., \& Samuel, R. (2017). The role of perceived stress and self-efficacy in young people's life satisfaction: A longitudinal study. Journal of Youth and Adolescence, 46: 78-90.

Caprara, G. V., \& Steca, P. (2005). Self-efficacy beliefs as determinants of prosocial behavior conducive to life satisfaction across ages. Journal of Social and Clinical Psychology, 24/2, 191-217.

Chambers, R. A., Taylor, J. R., \& Potenza, M. N. (2003). Developmental neurocircuitry of motivation in adolescence: A critical period of addiction vulnerability. The American Journal of Psychiatry,160/6, 1041-1052.

Charrow, C. B. (2006). Self-efficacy as a predictor of life satisfaction in older adults (Unpublished Dissertation). New York: Adelphi University. 
Chipuer, M., Bramston, P., \& Pretty, G. (2003). Determinants of subjective quality of life among rural adolescents: a developmental perspective. Social Indicators Research, $61 / 1,79-95$.

Cicognani, E., \& Zani, B. (2011). Alcohol use among Italian university students: The role of sensation seeking, peer group norms and self-efficacy. Journal of Alcohol and Drug Education, 55/2, 17-36.

Cloninger, C. R., Svrakic, D. M., \& Przybeck, T. R. (1993). A Psychobiological model of temperament and character. Archives of General Psychiatry, 50/12, 975-990.

Coffman, D. L., \& Gilligan, T. D. (2002). Social support, stress, and self-efficacy: Effects on students satisfaction. Journal of College Student Retention: Research, Theory \& Practic, 4/1, 53-66.

Costa, P. T., \& McCrae, R. R. (1992). NEO-PI-R: Revised NEO personality inventory (NEO-PI-R). Odessa, FL: Psychological Assessment Resources.

Creswell, J. (2002). Educational research: Planning, conducting, and evaluating quantitative and qualitative research. Upper Saddle River, NJ: Merrill Prentice Hall.

Curran, M. F., Fuertes, J. N., Alfonso, V. C., \& Hennessy, J. J. (2010). The association of sensation seeking and impulsivity to driving while under the influence of alcohol. Journal of Addictions \& Offender Counseling, 30: 84-98.

Çelik, E. (2015). Kendini gizleme ve yaşam doyumu arasındaki ilişkide heyecan arayışının aracılık ve moderatör rolü. Eğitim ve Bilim, 40/181, 349-361.

Çelik, E., \& Raba, S. (2017). Heyecan arayışının yaşam doyumu ile proaktif kişilik arasındaki ilişkide baskıcı etkisi. Mediterranean Journal of Humanities, 7/1, 123-134.

Çelik, E., \& Turan, M. E. (2016). A study on the psychometric features of the Turkish version of the brief sensation seeking scale (BSSS-8) for young adults and the relation between sensation seeking and life satisfaction. International Journal of Educational Research Review, 1: 29-38.

Çivitçi, A. (2009). İlköğretim öğrencilerinde yaşam doyumu: Bazı kişisel ve ailesel özelliklerin rolü. Uludağ Üniversitesi Eğitim Fakültesi Dergisi, 22/1, 29-52.

Çıkrıçı, Ö., \& Odacı, H. (2016). The determinants of life satisfaction among adolescents: The role of metacognitive awareness and self-efficacy. Social Indicator Research, 125: 977-990.

Diehm, R., \& Armatas, C. (2004). Surfing: An avenue for socially acceptable risktaking, satisfying needs for sensation seeking and experience seeking. Personality and Individual Differences, 36: 663-677.

Diener, E., \& Suh, E. M. (1997). Measuring quality of life: Economic, social and subjective indicators. Social Indicators Research, 40/1-2, 189-216. 
Diener, E., Emmons, R. A., Larsen, R. J., \& Griffin, S. (1985). The life satisfaction scala. Journal Personality of Assessment, 49/1, 71-75.

Diener, E., Oishi, S., \& Lucas, R. E. (2003). Personality, culture, and subjective wellbeing: Emotional and cognitive evaluations of life. Annual Review of Psychology, 54: 403-425.

Donohew, L., Zimmerman, R. S., Cupp, P. S., Novak, S., Colon, S., \& Abell, R. (2000). Sensation seeking, impulsive decision-making, and risky sex: implications for risktaking and design of interventions. Personality and Individual Differences, 28: 10791091.

Dönmez, M. M. (2007). Meslek lisesi öğrencilerinin atılganlık düzeylerine göre yaşam doyumu ve duyguları ifade etme eğilimlerinin karşılaştırılması (Yayınlanmamış Yüksek Lisans Tezi). Ankara Üniversitesi Eğitim Bilimleri Enstitüsü, Ankara.

Durak, M., Senol-Durak, E., \& Gencoz, T. (2010). Psychometric properties of the life satisfactionscale among Turkish university students, correctional officers, and elderly adults. Social Indicators Research, 99/3, 413-429.

Ehrenberg, M. F., Cox, D. N., \& Kopman, R. F. (1991). The relationship between selfefficacy and depression in adolescents. Adolescence: 26, 361-374.

Erturan,İ., Aktepe, E., Kocaman, O., Sönmez, Y., Başak, P. Y., Ceyhan, A. M., \& Baysal Akkaya, V. (2014). Akneli ergenlerin yaşam kalitesi, yalnızlık ve yaşam doyumu düzeylerinin değerlendirilmesi. Türkderm, 48: 172-6.

Frisch, M. B. (2006). Quality of life therapy: Applying a life satisfaction approach to positive psychology and cognitive therapy. New York, NY: John Wiley \& Sons, Ltd.

Gilman, R., \& Huebner, E. S. (2006). Characteristics of adolescents who report very high life satisfaction. Journal of Youth and Adolescence, 35: 311-319.

Giovanni, M. V., Gerbino, M., Pastorelli, C., \& Caprara, G. V. (2007). Multi-faceted self-efficacy beliefs as predictors of life satisfaction in late adolescence. Personality and Individual Differences, 43/7, 1807-1818.

Gündoğar, D., Gül, S. S., Uskun, E., Demirci, S., \& Keçeci, D. (2007). Üniversite öğrencilerinde yaşam doyumunu yordayan etkenlerin incelenmesi. Klinik Psikiyatri 10/1, 14-27.

Huebner, E. S., Antaramian, S., Hills, K., Lewis, A., \& Saha, R. (2010). Stability and predictive validity of the BMSLSS. Child Indicators Research, 4: 161-168.

Jonah, B. A., Thiessen, R., \& Au-Yeung, E. (2001). Sensation seeking, risky driving and behavioral adaptation. Accident Analyasis and Prevention, 33/5, 679-684.

Jorgensen, R. S., \& Johnson, J. H. (1990). Contributors to the appraisal of major life changes: Gender, perceived controllability, sensation seeking, strain, and social support. Journal of Applied Social Psychology, 20/14, 1123-1138. 
Karasar, N. (2006). Bilimsel Araştırma Yöntemi. Ankara: Nobel Yayın Dağıtım.

Koçak, Ö. F. (2016). Kişilerarası çatı̧̧malar ve yaşam doyumu iliş̧kisi: Üniversite öğrencileri üzerinde bir araştırma. Journal of International Social Research, 9/43, 19561977.

Kopstein, A. N., Crum, R. M., Celentano, D., \& Martin, S. S. (2001). Sensation seeking needs among 8th and 11th graders: Characteristics associated with cigarette and marijuana use. Drug and Alcohol Dependence, 62: 195-203.

Köker, S. (1991). Normal ve sorunlu ergenlerin yaşam doyumu düzeylerinin karş̧laş̧ıırılması (Yayınlanmamış Yüksek Lisans Tezi). Ankara Üniversitesi, Sosyal Bilimler Enstitüsü.

Lucas, R. E., Diener, E., \& Suh, E. (1996). Discriminant validity of well-being measures. Journal of Personality and Social Psychology, 71: 616-628.

Luszczynska, A., Scholz, U., \& Schwarzer, R. (2005). The general self-efficacy scale: Multicultural validation studies. The Journal of Psychology, 139/5, 439-57.

Oishi, S., Schimmack, U., \& Colcombe, S. J. (2003). The contextual and systematic nature of life satisfaction judgments. Journal of Experimental Social Psychology, 39/3, 232-247.

Özgüngör, S. (2009). Postmodern değerler, kimlik oluşumu ve yaşam doyumu. Türk Psikolojik Danışma ve Rehberlik Dergisi, 4/31, 32-42.

Hoyle, R. H., Stephenson, M. T., Palmgreen, P., Lorch, E. P., \& Donohew, R. L. (2002). Reliability and validity of a brief measure of sensation seeking. Personality and individual differences, 32/3, 401-414.

Reigal, R. Videra, A., \& Gil, J. (2014). Physical exercise, general self-efficacy and life satisfaction in adolescence. Revista Internacional de Medicina y Ciencias de la Actividad Física y el Deporte, 14/55, 561-576.

Reyes-Pulliza, J. C., Moscoso-Alvarez, M. R., Rodriguez-Figueroa L., \& Coln, H. (2014) Sensation seeking as a risk factor for drinking and driving among secondary school students in Puerto Rico. In 142nd APHA Annual Meeting and Exposition, New Orleans, 15-19, 2014.

Romer, D. (2010). Adolescent risk taking, impulsivity, and brain development: Implications for prevention. Developmental Psychobiology, 52/3, 263-276.

Sahranç, Ü. (2008). Bir durumluk akış modeli: Stres kontrolü, genel öz yeterlik, durumluk kaygı, yaşam doyumu ve akış ilişkileri. The Journal of SAU Education Faculty, 122-144.

Santrock, J. W. (2012). Ergenlik (Çev. Diğdem Müge Siyez). Ankara: Nobel Yayınevi. 
Scherbaum, C. A., Cohen-Charash, Y., \& Kern, M. J. (2006). Measuring general self efficacy: A comparison of three measures using item response theory. Educational and Psychological Measurement, 66/6, 1047-1063.

Scholz, U., Gutierrez-Dona, B., Sud, S., \& Schwarzer, R. (2002). Is general self-efficacy a universal construct? Psychometric findings from 25 countries. European Journal of Psychological Assessment, 18: 242-251.

Schwarzer, R., \& Jerusalem, M. (1995). Generalized self-efficacy scale. In J. Weinman, S. Wright, \& M. Johnston (Eds.), Measures in Health Psychology: A User's Portfolio Causal and Control Beliefs (pp. 35-37). Windsor, UK: NFER-Nelson.

Smith, R. E., Ptacek, J. T., \& Smoll, F. L. (1992). Sensation seeking, stress and adolescent injuries: A test of stress buffering, risk-taking, and coping skills hypotheses. Journal of Personality and Social Psychology, 62: 1016-1024.

Smorti, M. (2014). Sensation seeking and self-efficacy effect on adolescents risky driving and substance abuse. Procedia - Social and Behavioral Sciences, 140: 638-642.

Stegman, S. (2011). The relation between sensation seeking and life satisfaction (Unpublished PhD thesis). Fort Hays State University.

Şahan, H., Tekin, M., Yıldız, M., Eraslan, M., Yıldız, M., Sim, H., \& Yarar, N. D. (2012). Examination of self-efficacy and life satisfaction levels of students receiving education in schools of physical education and sports. World Academy of Science, Engineering and Technology, 66: 942-944.

Şeker, B. D., \& Akman, E. (2015). Farklı ülkelerden üniversite öğrencilerinin psikolojik iyi olma ve yaşam doyumları üzerine bir araştırma. CBÜ Sosyal Bilimler Dergisi, 13/1, 106-119.

Tabachnick, B. G., \& Fidell, L. S. (2007). Using Multivariate Statistics. Boston, MC: Pearson Education.

Umaz, D. (2010). Diyarbakır'daki ilköğretim öğretmenlerinin öz-yeterlik düzeyi ve yaşadıkları iletişim sorunları (Yayımlanmamış Yüksek Lisans Tezi). Yeditepe Üniversitesi, Sosyal Bilimler Enstitüsü, İstanbul.

Uysal, İ. (2013). Akademisyenlerin genel öz-yeterlik inançları: AİBÜ eğitim fakültesi örneği. Trakya Üniversitesi Eğitim Fakültesi Dergisi, 3/2, 144-151.

Yanovitzky, I. (2005). Sensation seeking and adolescent drug use: The mediating role of association with deviant peers and pro-drug discussions. Health Communication, 17/1, 67-89.

Yetim, U. (2003). The impacts of individualism/collectivism, self-esteem, and feeling of mastery on life satisfaction among the Turkish university students and academicians. Social Indicators Research, 61/3, 297-317.

Zuckerman, M. (1990). The psychophysiology of sensation seeking. Journal of Personality, 58/1, 313-345. 
Zuckerman, M. (1994). Behavioral expressions and biosocial bases of sensation seeking. Cambridge University Press.

Zuckerman, M., \& Kuhlman, D. M. (2000). Personality and risk taking: common biosocial factors. Journal of Personality, 68: 999-1029. 